\title{
EDITORIAL
}

\section{A Red Card for Plagiarism}

\author{
Eka R Gunardi
}

\section{INTRODUCTION}

According to Kamus Besar Bahasa Indonesia, plagiarism is an act of copying against copyrights. ${ }^{1,2}$ This includes copying texts, paragraphs, sentences, word, research content, opinion or idea, and admitting it as his or her own. 3,4

A study on 40 students suspected of plagiarism has called the act of plagiarism as a destruction of academic integrity and honesty that has long been honored. ${ }^{1}$

A simple study conducted in Surakarta involving 20 teachers and 50 students in 5 Junior High Schools and 5 Senior High Schools in 2011 found that internet plagiarism is on the rise. This was found to be due to laziness and lack of references. The majority of teachers questioned in connection to the study, considered plagiarism as being acceptable as long as the task is submitted on time. Students who plagiarize tend to give up more easily, lack creativity, has difficulty controlling their emotions and show decline in achievement. ${ }^{5}$

It seems that plagiarism is an issue that needs to be tackled together. In 2009, the University of Indonesia published a decree issued by its Rector number: 208/SK/R/UI/2009 on the definition, act, prevention, and consequences towards plagiarism in academic circles within UI. ${ }^{6}$ The Department of Obstetrics and Gynecology has also applied the same guidelines, by giving red cards to several residents. Other efforts established to prevent plagiarism include training and education on plagiarism and citation techniques in academic writing.

\section{Cause}

Information technology, also known as the internet, began to flourish in Indonesia in the 1990s, and brought about a major change in information exchange. As a result, an increase in plagiarism was observed, as literature published on the Internet is extremely easy to access and copy. Another important reason is limitations in English language capability, especially in countries where English is not used as the main language. Furthermore, a misperception on plagiarism and misunderstanding of correct citation techniques exists.

A study by Ashworth and Banniter revealed that the cause of plagiarism is not solely rooted in the laziness of the student, but can also be explained because of an apparent misunderstanding on what the teacher has delivered and the task given, so that the student does not consider plagiarism as a moral issue. ${ }^{8}$

A study reported that $10-30 \%$ of plagiarism cases occurs due to citation error, including the absence of journal articles and authors. Several studies have discovered plagiarism in as much as 1 in 20 resident entrance test essay applications. ${ }^{9}$

\section{Impact}

Plagiarism may sound simple, but it carries an enormous and long-term impact. Students proven to commit the act of plagiarism were found to show unethical attitudes during his or her work. ${ }^{9}$ These students also had a higher tendency to give up more easily, have lack of creativity, show difficulty in controlling emotion, and decline in achievement was also observed in these students. ${ }^{5}$

\section{Strategies to Avoid Plagiarism}

After considering the cause and impact of plagiarism, we hope that readers have the motivation to improve 
their writing and citation skills in an effort to avoid plagiarism. Here are some points to avoid plagiarism. ${ }^{10}$

When writing an essay, do not only report or copy literatures or findings, but also add your interpretation, analysis, and argumentation based on those references. Use your own phrasing vocabulary, instead of copying words from the original author.

University education is not merely to obtain grades, but also a process to enhance the students' writing and research skills. When a problem occurs, a student should meet his/her academic tutor, module coordinator, or head of study program, and utilize available resources such as textbooks and training modules. When using others' sentences, use quotation and provide footnotes regarding the reference. If not, use your own words. When quoting a reference, immediately add the reference number or citation. This will help prevent unintentional plagiarism and assists in building a reference list. Articles on general knowledge do not require citations. When in doubt, place it in the reference list.

Although not recommended, when copying a sentence, use quotation and provide the correct source or reference. Nevertheless, rewriting a sentence from another reference with one's own words is advised. If the quote was modified, explain the modification. Do not copy a whole paragraph; read and rewrite with your own words. If you require material in significant amounts, paraphrase the material. If you need to display pictures, graphs, or tables; not only should references be specified, but a clear and complete explanation should also be provided.

\section{CONCLUSION}

Medical education requires students to have the ability to appraise literatures and write scientific articles. The burden of writing and providing citation causes the students to be prone to plagiarism. In the era of vastly expanding varieties of technology, the temptation to achieve something by way of a shortcut is commonly encountered. But do we have to get caught or punished first before understanding about plagiarism?

One simple concept in preventing plagiarism is to read more, in an effort to attain better writing ability. The same concept has been commanded by the Prophet Muhammad SAW when receiving the first verse in the Koran: "Iqra" (read).

\section{References}

1. Herqutanto. Plagiarisme, runtuhnya tembok kejujuran akademik. [Online]. Available from: URL:http://journal.ui.ac.id/index. php/eJKI/article/viewFile/1589/1335 [Accessed 23 August 2014].

2. Kamus Besar Bahasa Indonesia. Edisi online versi 1.3. Available from: URL:http://ebsoft.web.id [Accessed on 20 April 2012].

3. Sastroasmoro S. Beberapa catatan tentang plagiarisme. Maj Kedokt Indon 2006; 56(1): 1-6.

4. Merriam-Webster's collegiate dictionary. 11 th ed. Springfield: Merriam-Webster Inc; 2008. Plagiarism; p.1020.

5. Niam MM, Pertiwi AZ. Dampak plagiarisme internet terhadap karakter pelajar Kota Surakarta. [Online]. Available from: URL:http://kakniam.files.wordpress.com/2011/04/dampak-plagiarisme-terhadap-karakter-pelajar-kota-surakarta.pdf [Accessed on 23 August 2014].

6. Universitas Indonesia. Pedoman penyelesaian masalah plagiarisme yang dilakukan oleh sivitas akademika Universitas Indonesia. [Online]. Available from: URL:http://kurfak2005.fk.ui.ac.id/SK\%20Rektor\%20208\%202009\%20PLAGIARISME.pdf [Accessed on 23 August 2014].

7. Cole AF. Plagiarism in graduate medical education. Fam Med 2007; 39(6): 436-8.

8. Ashworth P, Bannister P, Thorne P. Guilty in whose eyes? University students' perceptions of cheating and plagiarism in academic work and assessment. Stud High Educ 1997; 22: 187-203.

9. Segall S. Study plagiarism in medical residency application. Boston: Harvard Medical School; 2007.

10. Rogers SM. Mastering scientific and medical writing. Sticking to your word : avoiding plagiarism. Berlin: Springer; 2014: 75-80 